\title{
Peningkatan Produksi MOCAF dengan Rancang Bangun Alat Pemotong
}

\author{
Widayat ${ }^{1}$, Hadiyanto ${ }^{1}$, Hantoro Satriadi ${ }^{1}$, Meiny Suzery ${ }^{2}$ dan Irawan Arief Budianto ${ }^{3}$ \\ 1Departemen Teknik Kimia Fakultas Teknik Universitas Diponegoro Jl. Prof. Soedarto SH Tembalang Semarang; e- \\ mail: widayat@live.undip.ac.id \\ ${ }^{2}$ Departemen Kimia Fakultas Sains dan Matematika Universitas Diponegoro Jl. Prof. Soedarto SH Tembalang \\ Semarang \\ ${ }^{3}$ PT. MOCAF Solusindo Jl. Ir. Soekarno, Kwarasan, Grogol, Kabupaten Sukoharjo, Jawa Tengah
}

\begin{abstract}
ABSTRAK
Singkong merupakan tanaman pangan berupa perdu dengan nama lain ubi kayu, singkong atau kasape. Singkong dapat diubah menjadi tape, alkohol, MOCAF (Modified Cassava Flour) dan juga diambil tepung tapiokanya. MOCAF adalah tepung singkong yang telah mengalami proses modifikasi baik fisika, kimia atau biologi. PT MOCAF Solusindo merupakan produsen MOCAF dan berdomisili di Sukoharjo. Dalam perkembangan telah melakukan pemberdayaan masyarakat Kecamatan Matesih Kabupaten Karanganyar untuk mengolah singkong menjadi produk MOCAF. Permasalahan yang dihadapai oleh PT MOCAF Solusindo adalah beberapa proses masih menggunakan teknologi konvensional, seperti memotong dengan menggunakan pisau. Penelitian bertujuan melakukan kegiatan rancang bangun alat pemotong singkong bermesin. Alat pemotong terdiri dari pisau pemotong yang dihubungkan oleh tuas dan digerakkan oleh motor penggerak. Produksi MOCAF yang dilakukan di PT MOCAF Solusindo meliputi proses pengupasan, perajangan, perendaman atau fermentasi, penirisaan, pengeringan dan penepungan serta packing. Untuk proses pengupasan sampai pengeringan dilakukan dengan pemberdayaan masyarakat. Proses penepungan dan packing dilakukan oleh PT MOCAF Solusindo. Proses utama dalam produksi MOCAF di PT MOCAF Solusindo adalah fermentasi menggunakan mikroba. Mikroba dikembangkan dengan menggunakan bakteri Lactobacillus sp. Proses fermentasi dilakukan selama 20- 24 jam. Kegiatan ini dilakukan pada proses pengirisan /pemotongan singkong. Alat ini dapat meningkatkan kapasitas pemotongan yang semula hanya $50-56 \mathrm{~kg}$ per jam menjadi $250 \mathrm{~kg} / \mathrm{jam}$. Dengan demikian dapat meningkatkan omzet dari PT. MOCAF Solusindo dari Rp. 21.000.000, menjadi Rp.35.000.000,- per bulan. Karakteristik produk MOCAF organoleptik, analisis citra dengan Scaning Electron Microscope (SEM). Warna produk MOCAF yang diperoleh telah memenuhi standar SNI (Standar Nasional Indonesia) dan hasil analisis citra morfologinya sudah mendekati citra dari tepung gandum.
\end{abstract}

Kata kunci: Singkong, MOCAF, Pemotong Singkong, Peningkatan Kapasitas, Analisis Produk

\begin{abstract}
Cassava is a shrubbery crop which can be called Manihot esculenta or kasape in Javanese. Cassava can be converted into tape, alcohol, MOCAF (Modified Cassava Flour) and tapioca flour. MOCAF is a flour derived from cassava that has undergone physical, chemical and biological modification process. PT MOCAF Solusindo is a MOCAF manufacturer located in Sukoharjo. They had developed community empowerment in Matesih District Karanganyar Regency to process cassava into MOCAF products. One of the problems that occured to the company was but not limited to the usage of conventional technology (knives) in the cutting process. Consequently, this research aims to design a cassava cutting machine. The machine consisted of knives which are connected to a lever driven by motors. MOCAF production steps in PT MOCAF Solusindo include peeling, mincing, soaking and fermentation, filtering, drying and flour-coating and packing. The steps starting from peeling to drying were carried out in the community empowerment, while flour-coating and packing by PT MOCAF Solusindo. The main process on the MOCAF production was microbial fermentation. Microbes were developed using Lactobacillus sp., with fermentation process taking 20-24 hours. This process was carried out whilst cutting process takes place. The cutting machine can increase the original capacity of only $50-56 \mathrm{~kg}$ per hour to $250 \mathrm{~kg} /$ hour, which raised the revenue of the company from Rp. 21,000,000, to Rp.35,000,000, - per month. The product characteristics were organoleptically tested. The color of the flour has met the SNI requirement and physical morphology analysis using SEM showed similarity to wheat flour.
\end{abstract}

Keywords: Cassava, MOCAF, Cutting Tool, Capacity Improvement, Product Analysis

Citation: Widayat, Hadiyanto, Satriadi H, Suzery M., and Budianto, I.A., (2019). Rancang Bangun Alat Pemotong dalam Proses Produksi MOCAF di Desa Matesih. Jurnal Ilmu Lingkungan, 17(3), 515-521, doi:10.14710/jil.17.3.515-521 


\section{Latar Belakang}

Kabupaten Karanganyar merupakan salah satu Kabupaten di Provinsi Jawa Tengah yang terdiri dari 17 kecamatan dan 177 desa yang berbatasan langsung dengan Kabupaten Sragen di sebelah utara, Kabupaten Wonogiri dan Kabupaten Sukoharjo di sebelah selatan, Kota Surakarta dan Kabupaten Boyolali di sebalah Barat, serta Provinsi Jawa Timur di sebelah timur. Kecamatan Matesih merupakan salah satu kecamatan yang ada di Kabupaten Karanganyar. Kabupaten Karanganyar sebagian tanahnya merupakan tanah pertanian yang memiliki potensi cukup baik bagi pengembangan tanaman agro industri, salah satunya adalah singkong (Pemda Kab. Karanganyar, 2017).

Singkong merupakan tanaman pangan berupa perdu dengan nama lain ubi kayu, singkong atau kasape(Ahit dkk, 1981; Cock, 1992; (Gardner dkk, 1991; Alves 2002). Pada umumnya singkong dijual mentah dan diubah menjadi produk olahan seperti tape, alkohol, tepung tapioka, dan MOCAF.

MOCAF merupakan tepung singkong yang telah mengalami proses modifikasi baik secara fisika, kimia maupun biologi (Ahit dkk, 1981). MOCAF memiliki karakteristik seperti tepung terigu tetapi memiliki tekstur yang lebih kasar dari tepung terigu, sehingga dapat digunakan sebagi bahan pengganti terigu atau campuran terigu 30\%-100\% dan dapat menekan biaya konsumsi tepung terigu 20\%-30\%. tepung MOCAF. Tepung ini banyak digunakan dalam pembuatan beras analog (Yuwono dkk, 2013), pembuatan cokies (Anggraeni dkk, 2018), pembuatan es kream dari susu kedelai (Kusumastuti dan Andriani, 2017) , olahan keju (Priadi dkk, . Tepung ini memiliki kelebihan bebas gluten, sehingga aman bagi anak-anak yang memiliki kebutuhan khusus.

PT. MOCAF Solusindo merupakan salah satu industri yang proses produksi dengan pemberdayaan masyarakat di Kecamatan Matesih. Dalam pemberdayaan masyarakat meliputi kegiatan pengupasan singkong, pencucian singkong, pemotongan singkong sampai pengeringan singkongnya. Permasalahan yang ada di PT. MOCAF Solusindo adalah proses produksi MOCAF sebagian masih mengandalkan teknologi konvesional karena program pemberdayaan masyarakat yang diterapkan dalam proses produksinya. Pada kegiatan pemberdayaan masyarakat lebih banyak menggunakan peralatan seperti pisau. Pengupasan singkong dan pemotongan masih kendala karena membutuhkan waktu yang lama. Jika perusahaan harus mememnuhi kuota pasar, akan menjadi penghambat yang utama. Kegiatan ini bertujuan untuk meningkatkan produktifitas MOCAF dengan merancang bangun alat pemotong beserta ujicoba penggunaannya.

\section{Metode Pelaksanaan \\ 2.1. Alat dan Bahan}

Peralatan yang digunakan semuanya berasal dari PT. Solusindo Tirtatex yang merupakan bengkel untuk pembuatan mesin. Bahan yang digunakan adalah plate stainless steel, motor listrik dan kerangka. Bahan singkong digunakan untuk ujicoba alat pemotong dan produksi MOCAF. Bahan lain yang digunakan adalah air dan strain bakteri.

\subsection{Metode}

Metode pelaksanaan meliputi evaluasi industri PT. MOCAF Sulusindo, perbaikan proses, rancang bangun, demostrasi dan plotting, serta analisis produk. Evaluasi industri bertujuan untuk mengetahui proses yang ada saat ini dan menyelesaikan permasalahan. Hasil evaluasi menunjukkan adanya permasalahan dalam pemotongan bahan baku. Kegiatan yang dilakukan untuk mengatasi masalah ini adalah rancang bangun alat pemotong singkong. Untuk demonstrasi bertujuan meningkatkan keterampilan sumber daya manusia dari UKM mitra tentang tata cara pengoperasian dan pemeliharaan alat pemotong singkong. Pelatihan dan demonstrasi diberikan langsung pada UKM mitra tentang alat tersebut. Dengan kegiatan ini diharapkan UKM mitra dapat lebih intensif dalam menerima alih teknologi dan diharapkan pihak UKM mampu mengoperasikan alat tersebut secara mandiri.

\subsection{Analisis Produk}

Untuk proses pemotongan diamati waktu yang dibutuhkan pada kapasistas yang sama antara pemotongan konvensonal dan hasil kegiatan. Pemotongan dilakukan dengan menggunakan alat pemotong dan teknologi sederhana. Untuk produk MOCAF dilakukan analisis tekstur, warna dan anaisis morphologi dengan menggunakan Scaning electron Microscope (SEM). Pada analisis ini dilakukan pembandingan dengan tepung tapioka dan tepung gandum.

\section{Hasil dan Pembahasan \\ 3.1. Evaluasi}

Pelaksanaan survey dilakukan dengan mengadakan kunjungan ke UKM mitra. Pengumpulan data dilakukan dengan wawancara dan dialog. Nara sumber yang digunakan adalah pemilik PT. MOCAF Solusindo beserta perangkat Desa Matesih Kabupaten Karanganyar, Jawa Tengah.

PT MOCAF Solusindo menggunakan bahan baku singkong yang diperoleh dari Kab. Karanganyar dan sekitarnya. Diagram alir proses produksi tepung MOCAF di PT MOCAF Solusindo sebagaimana disajikan dalam Gambar 1. Proses yang dlakukan meliputi penyiapan bahan baku, proses fermentasi dan pengeringan dan pengepakan. Secara penahapan proses ini sama dengan yang dilakukan oleh Ahit dkk, 1981; Putri dkk, 2018; Diniyah dkk, 2018; Suhery dkk, 2013. 


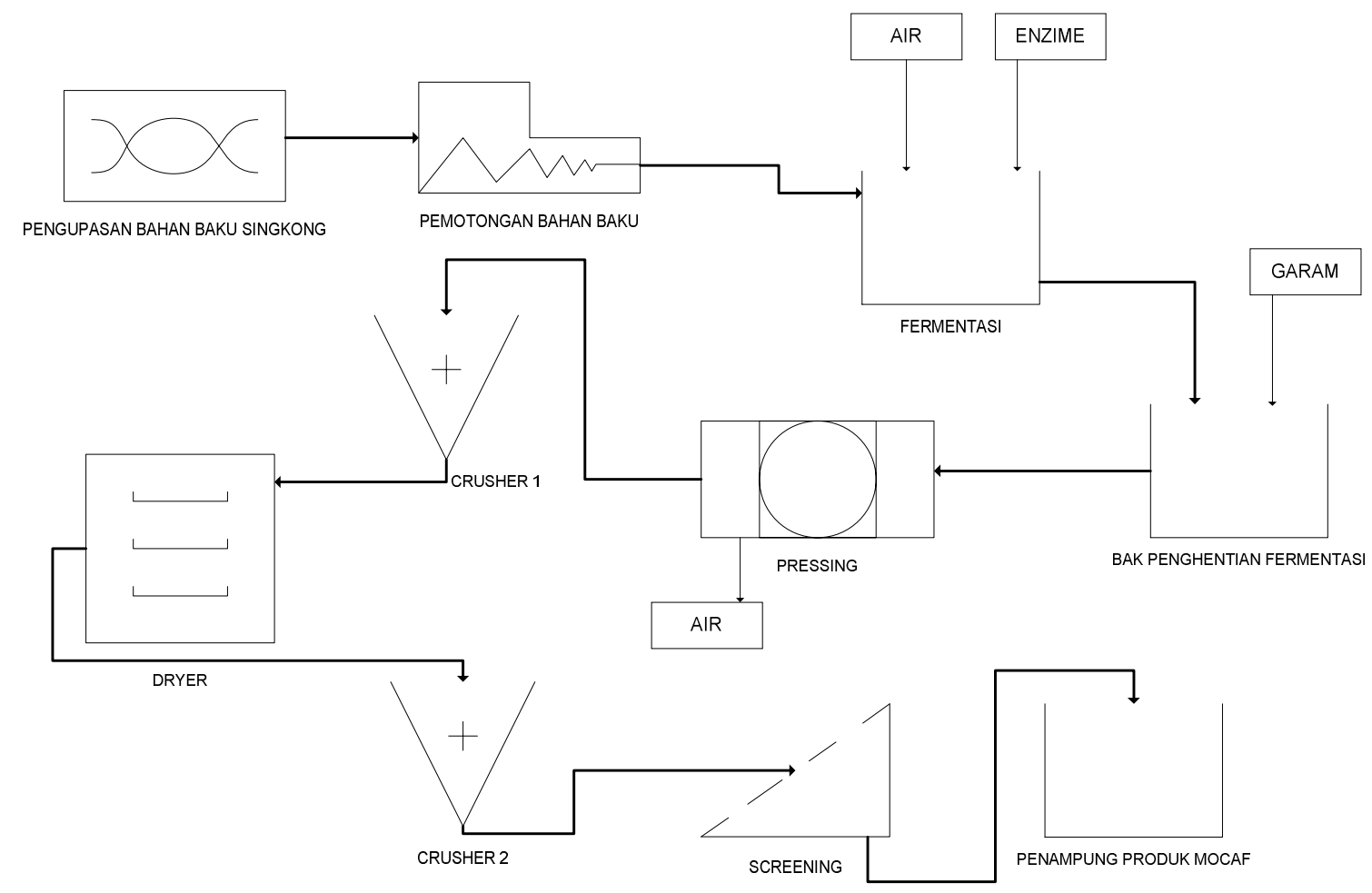

Gambar 1. Blok diagram proses produksi MOCAF di PT.MOCAF Solusindo

Penyiapan bahan baku yang dilakukan meliputi; pengupasan, pencucian dan pemotongan. Singkong dikupas kulitnya dengan menggunakan pisau.. Kegiatan penyiapan bahan baku dilakukan dengan pemberdayaan masyarakat yang ada di Kel. Matesih. Sistem yang digunakan adalah masyarakat akan diberikan biaya ganti produksi. Setiap $1 \mathrm{~kg}$ singkong yang dikupas masyarakat memperoleh biaya sebesar Rp. 500,-. Singkong yang telah dikupas selanjutnya dicuci dan direndam. Rendaman singkong selanjutnya dipotong untuk memperoleh chip singkong atau potongan kecil singkong. Proses pemotongan menggunakan teknologi sederhana sebagaimana disajikan dalam Gambar 2. Pisau diletakkan pada salah satu ujung dan digerakkan oleh tangan dalam memotong. Singkong digerakkan secara manual pada ketebalan tertentu dipotong. Ketebalan yang dipakai berkisar 0,5-1,5 cm. Proses pemotongan singkong terjadi, ketika tuas digerakkan ke bawah. Dengan teknologi ini membutuhkan waktu yang lama. Kelemahan ini menjadi titik terpenting dalam melaksanakan kegiatan ini. Produk yang dihasilkan selanjutnya dilakukan perendaman /fermentasi dalam bak-bak fermentasi. Untuk kapasistas besar dilakukan dalam bak /kolam dan untuk kapasitas kecil dilakukan dalam drum-drum dari plastic.

Proses tahap yang kedua adalah proses fermentasi. Proses fermentasi mengunakan mikroorganisme bakteri yaitu Laktobacillus. Strain diperoleh dengan cara membiakkan bakteri pada yakult dibiakkan di dalam media singkong. Media singkong diperoleh dari rendaman singkong selama 12 jam. Air rendaman selanjutnya dipanaskan untuk 517 sterilisasi dengan ditambahkan sari-sari buah seperti buah nanas dan mangga untuk meningkatkan kosentrasi gula. Proses sterilasi dilakukan sampai media mendidih dan didinginkan hingga suhu kamar serta ditambahkan dengan nutrien seperti sumber $\mathrm{N}$, $\mathrm{P}, \mathrm{K}$ yang berasal dari urea dan amonium kalium fosfat. Adonan difermentasikan secara anaerob selama 1 hari. Media siap digunakan untuk proses perendaman dalam produksi MOCAF.

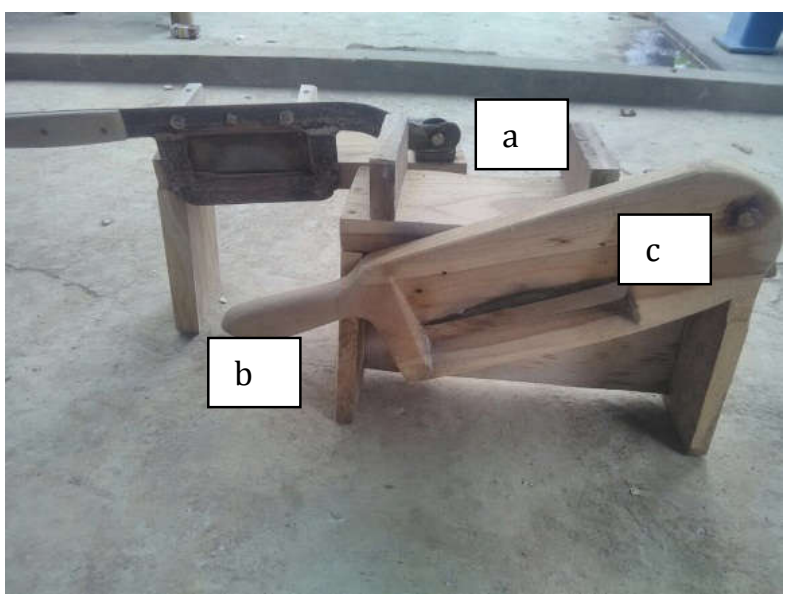

Gambar 2. Alat pemotong singkong (a. tempat singkong b. tuas c. pisau)

Potongan singkong selanjutnya dimasukkan ke dalam bak atau drum plastik dan ditambahkan dengan air dan strain sebanyak 20-30\%. Proses perendaman dilakukan selma 1-2 hari. Beberapa penelitian yang dilakukan proses penyiapan strain tidak dilakukan secara terpisah. Penggunaan bakteri laktobacillusakan memberikan pengaruh yang positif 
dalam pembentukan protein (Tandrianto dkk, 2014). PAda proses fermentasi kadar HCN akan dikonversi menjadi protein.

Produk fermentasi siap untuk dipanen dengan cara meniriskan dari cairan rendaman. Cairan rendaman dapat digunakan lebih lanjut sebagian dengan penambahan air. Dengan demikian penghematan srain dapat diperoleh. Proses penirisan cairan dilakukan dengan spinner. Chip hasil penirisan selanjutnya dikeringkan dengan media pengering matahari dan listrik atau biomassa. Proses pengeringan awal dibutuhkan waktu yang cepat. Hal ini bertujuan untuk mengurangi pertumbuhan jamur. Dengan demikian karakterisasi produk yang diperoleh akan terjaga. Pengeringan akhir dapat dilkukan pada ruangan yang tertutup. Produk chip yang kering dilakukan penghancuran /penepungan sehingga diperoleh tepung MOCAF yang siap untuk dilakukan packing dan pemasaran. Pengepakan dilakukan dalam bentuk plastik dan karaung $25 \mathrm{~kg}$. Untuk packing plastik berukuran 0,5 kg dan $1 \mathrm{~kg}$. Dokumentasi pengepakan produk tepung MOCAF disajikan dalam Gambar 3.

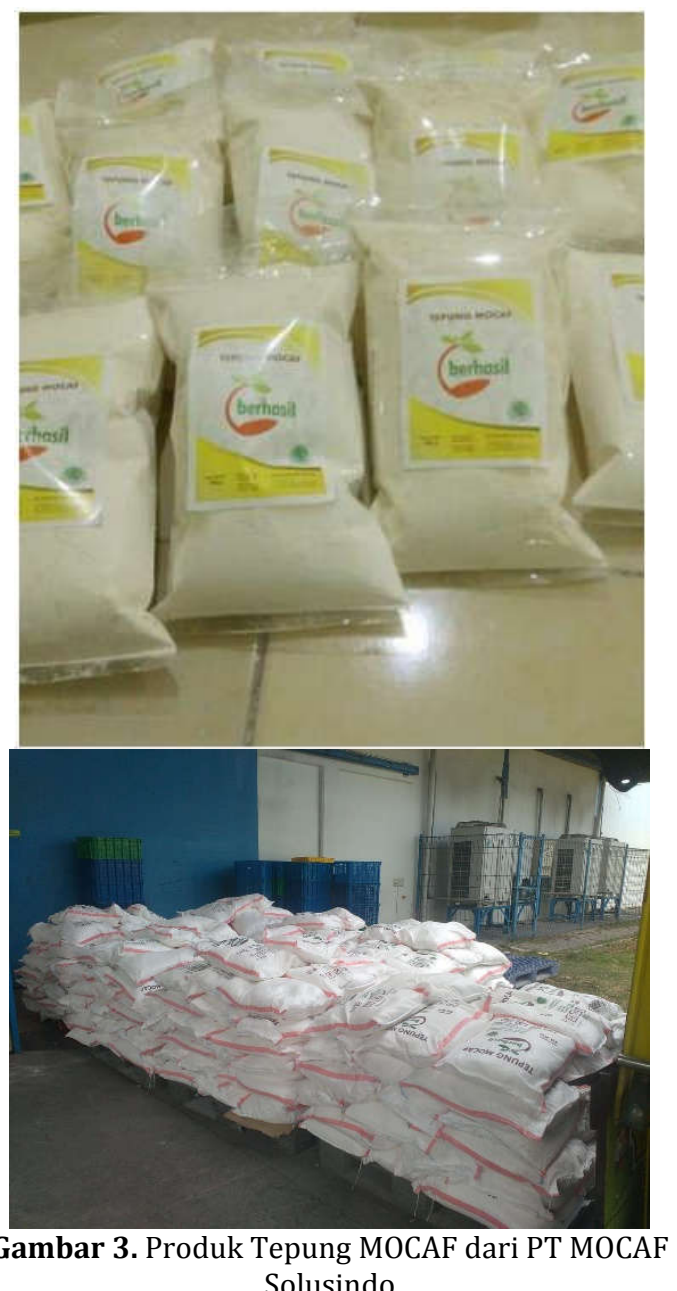

Hasil evaluasi terhadap proses produksi MOCAF di PT. MOCAF Solusindo dihasilkan beberapa permasalahan diantaranya penggunaan teknologi yang masih konvensional dalam proses pemotongan bahan baku, penirisan, dan proses pengeringan produk. Proses pemotongan yang masih konvensional menyebabkan proses produksi berjalan lambat. Dalam proses pemotongan masih dilakukan dengan pisau, belum digunakan mesin.

\subsection{Rancang Bangun Alat Pemotong}

Teknologi pemotongan yang dirancang untuk meningkatkan proses produksi merupakan teknologi pemotongan secara otomatis menggunakan mesin yang ada pada Gambar 4 .

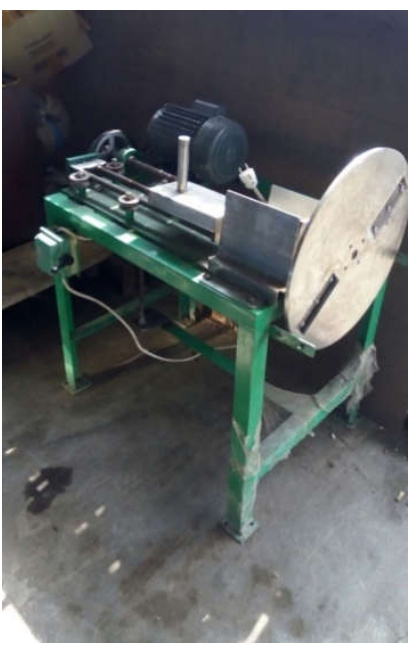

(a)

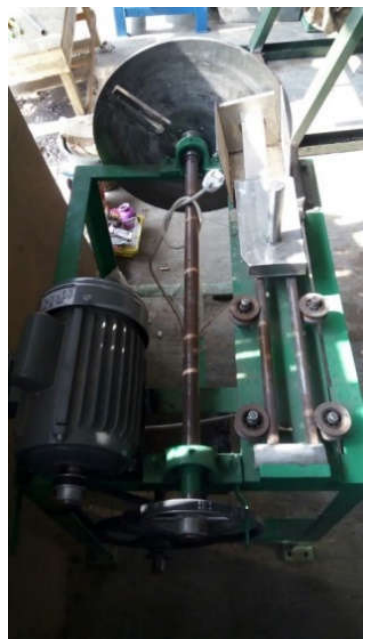

(b)
Gambar 4. Alat Pemotong Singkong tampak samping (a) dan tampak atas (b)

Konstruksi rangka menggunakan besi jenis siku dengan jenis logam ST37 yang merupakan logam konstruksi umum. Penggunaan material jenis ini selain untuk mengurangi beban juga untuk mempermudah proses manufaktur. Kerangka ini memiliki dimensi $60 \mathrm{~cm} \times 40 \mathrm{~cm} \times 60 \mathrm{~cm}$. rangka ini nantinya digunakan untuk menopang dinamo, poleey, as dan pisau potong serta komponen pendukung lainnya. Finishing alat dilakukan proses pendempulan dan kemudian dilakukan pengecatan untuk menghindari logam dari korosi. Untuk bagian tenaga penggerak digunakan dinamo $11 \frac{1}{2} \mathrm{Hp}$ dengan kecepatan putaran $1410 \mathrm{rpm}$. Pemilihan dinamo sebagai tenaga penggerak adalah agar emudahkan pengoperasian alat, dan daya dinamo yang tergolong rendah sehingga menekan biaya produksi. Tenaga yang dihasilkan dinamo ditransmisikan dengan menggunakan belt\&pulley. Pemilihan jenis bahan yang digunakan sebagai mata pisau adalah logam stainless steel. Pemilihan ini bertujuan untuk mengurangi resiko korosi karena pada penggunaannya alat ini akan mengalami kontak langsung dengan bahan yang mengandung air yang dapat mempercepat terjadinya korosi. Korosi yang terbentuk akan berbahaya dan mengurangi higinitas produk singkong.

\subsection{Ujicoba Peralatan}

Alat pemotong terdiri dari lubang masukan singkong, motor penggerak, tuas penghubung antara motor dengan pisau pemotong, dan lubang keluarann hasil potongan. Dokumentasi ujicoba alat pemotong singkong sebagaimana disajikan dalam Gambar 5 . 
Sistem kerja alat ini adalah motor penggerak akan menggerakkan tuas pisau pemotong yang selanjutnya secara otomatis. Hasil ujicoba alat pemotong adalah ukuran ketebalan chip singkong lebih seragam dan kapasitas potong sebesar $250 \mathrm{~kg}$ per jam. Kapasitas pemotongan ini lebih besar dibandingkan dengan teknologi konvesional yaitu 50-56 kg per jam. Peningkatan terjadi karena faktor pengerak pisau. Pisau dengan menggunakan mesin telah digerakkan oleh mesin dynamo, sehingga factor kelelahan bias diatasi dan juga kontinuitas dalam proses pemotongan bisa terjaga. Hal yang berlawanan terjadi pada proses pemotongan menggunakan pisau yang digeraakkan oleh tenaga manusia. Faktor kelelahan menjadi penghambat. Hal ini juga berakibat terhadap ukuran chip yang dihasilkan. Dengan Demikian adanya alat pemotong ini sangat membantu proses peroduksi terutama pemotongan singkong sebelum fermentasi.
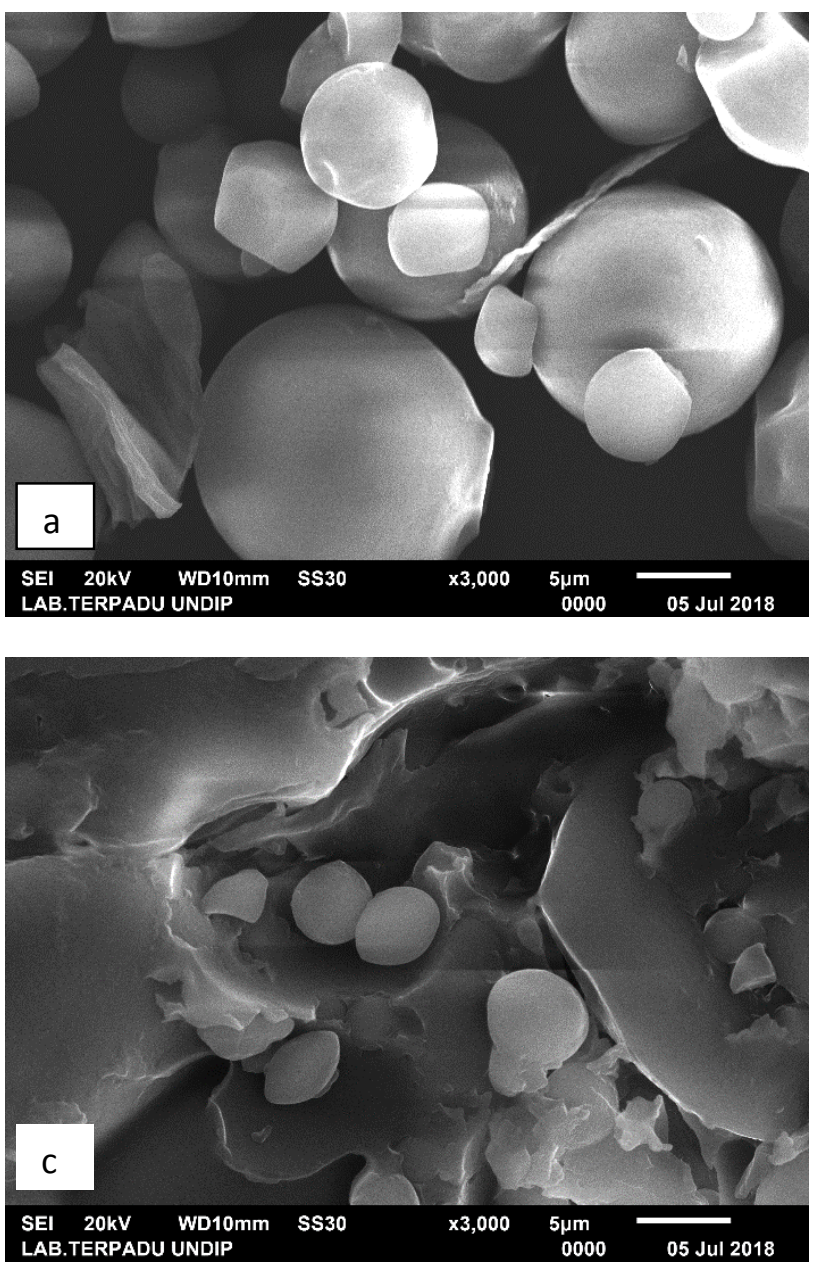

Gambar 5. Hasil foto citra morfologi pada perbesaran 300x (a. Tepung MOCAF, b. Tepun Tapioka dan c. tepung gandum)

Hasil citra morfologi pada Tepung MOCAF dan Tepung tapioka memiliki morfologi dengan bentuk bulat dan rata. Diameter pada permukaan Tepung tapioka lebih besar dibandingkan pada permukaan Tepung MOCAF. Hal ini menyebabkan luas permukaan dari Tepung MOCAF lebih besar dibandingkan pada Tapioka. Singkong mengandung

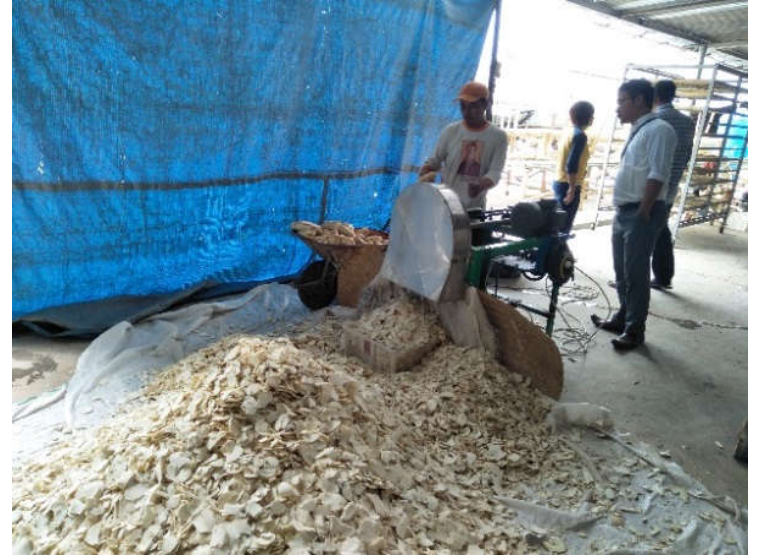

Gambar 5. Proses Pemotongan Singkong dengan Alat Potong Mesin

\subsection{Karakterisasi Produk Tepung MOCAF}

Karakterisasi terhadap tepung MOCAF dilakukan dengan analisis sitra morfologi dan analisis sifat fisik dan kimia. Hasil analsiis morfologi sebagaimana disajikaan dalam Gambar 5. Hasil analisis terhadap parameter fisik dan kimia disajikan dalam Tabel 1.

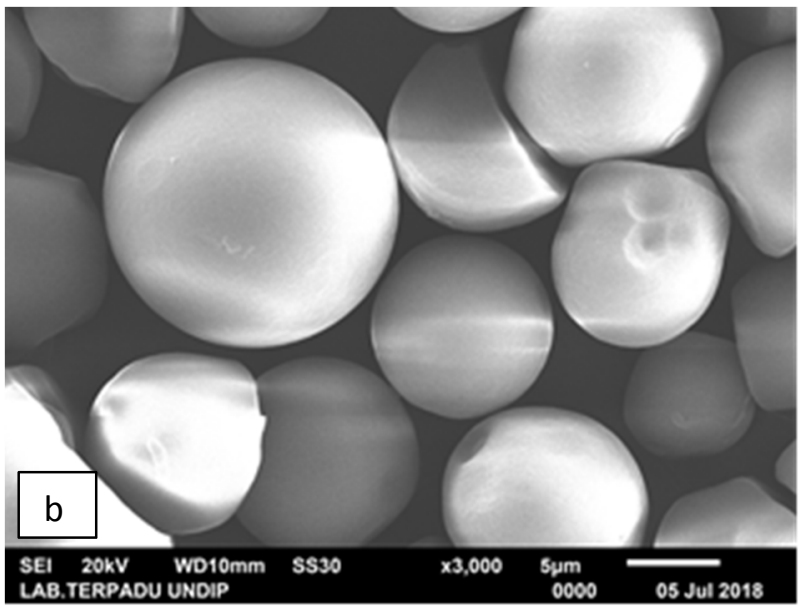

tepung tapioca /kanji yang merupakan bagian karbohidrat yang tidak larut dalam air. Dengan bentuk tersebut menyebabkan citra morfologi dari tepung MOCAF dan tapioca memiliki butiran yang terpisah. Bentuk butiran pada keduanya juga sama. Hal ini sesuai juga dengan analisis citra 
morfologi yang dilakukan oleh Wang dkk, (2018) dan Suhery dkk (2013).

Pada hasil citra morfologi dari tepung gandum memiliki bentuk morfologi permukaan yang tidak merata, kasar dan terdapat gumpalan gumpalan. Hal ini disebabkan tidak adanya kanji pada gandum dan mengandung gluten, sehingga memungkinkan terbentukan agglomerasi pada saat dianalisis.

Tabel 1. Hasil analisis tepung MOCAF PT MOCAF Solusindo

\begin{tabular}{|c|c|c|c|c|}
\hline Parameter & Satuan & Nilai & Batas analisis & Metode \\
\hline Kadar air & & $6,4726 \pm 0,4641$ & Maks 13 & \multirow{4}{*}{ SNI 0128911997} \\
\hline Kadar abu & & $1,4878 \pm 0,2559$ & Maks 1,5 & \\
\hline Serat kasar & $\%$ Berat & $2,000 \pm 0,0028$ & Maks 2 & \\
\hline Lemak & & $5,6439 \pm 0,1634$ & - & \\
\hline Protein & & $0,0035 \pm 0,0064$ & - & Bradford \\
\hline Derajat asam & $\begin{array}{l}\mathrm{ml} \mathrm{NaOH} / \\
100 \mathrm{gr}\end{array}$ & $6,4 \pm 0,000$ & Maks 4 & SNI $7622: 2016$ \\
\hline Nilai kalor & $\mathrm{kal} / \mathrm{gr}$ & $3.440,16$ & - & Bomb Kalorimeter \\
\hline Jumlah bakteri & koloni/g & 10 & Maks $1 \times 10^{4}$ & Total Plate Count \\
\hline Kehalusan Mesh-100 & $\%$ & 95 & Min. 90 & \multirow{3}{*}{ SNI 01-2891-1992 point 14} \\
\hline Kehalusan-Mesh-100 & $\%$ & 80 & Maks. 100 & \\
\hline Kehalusan- Mesh 80 & $\%$ & 98,89 & - & \\
\hline $\mathrm{Pb}$ & $\mathrm{mg} / \mathrm{kg}$ & Not detected & 0,009 & \multirow{6}{*}{ 18-13-1/MU/SMM-SIG, ICP-OES } \\
\hline $\mathrm{Cd}$ & $\mathrm{mg} / \mathrm{kg}$ & Not detected & 0,00011 & \\
\hline $\mathrm{Sn}$ & $\mathrm{mg} / \mathrm{kg}$ & Not detected & 3,38 & \\
\hline $\mathrm{Hg}$ & $\mathrm{mg} / \mathrm{kg}$ & Not detected & 0,004 & \\
\hline As & $\mathrm{mg} / \mathrm{kg}$ & Not detected & 0,008 & \\
\hline $\mathrm{SO}_{2}$ & $\%$ Berat & Not detected & Negatif & \\
\hline Salmonella sp. & $/ 25 \mathrm{~g}$ & Negative & - & SNI ISO 6579.2018 \\
\hline
\end{tabular}

Tabel 1 menunjukkan bahwa secara keseluruhan telah memenuhi persyaratan dari produk tepung MOCAF kecuali pada dearjat keasaman. Untuk parameter kadar air, kadar abu, kadar serat ksar, jumlah bakteri telah memenuhi persyaratan. Derajat keasaman merupakan parameter untuk mengukur banyaknya $\mathrm{NaOH}$ (Natrium Hidroksida) untuk menetralkan asam dalam setiap 100 gram bahan baku. Nilai yang besar disebabkan masih tersisanya asam pada tepung MOCAF. Asam terbentuk selama proses fermentasi akibat danya aktifitas metabolism mikroba atau enzimatik. Dalam produksi ini digunakan bakteri Laktobaciluus sp, sehingga memungkinkan terbentukanya asam laktat. Hal ini juga diperoleh pada penelitian Putri dkk (2018) bahkan diperoleh sampai $\mathrm{pH}$ 4. Untuk parameter serat kasar masih memenuhi, karena selama proses fermentasi akan terjadi proses hidrolisis serat (seperti selulosa dan hemiselulosa) menjadi gula. Untuk jumlah koloni bakteri menunjukkan nilai yang positif. Hal ini berarti bahwa selama proses produksi higinitas dan kebersihan selalu dijaga oleh PT MOCAF Solusindo.

\section{Kesimpulan}

Rancang bangun dan manufaktur mesin pemotong singkong telah dilakukan. Uji coba alat pemotong telah dilakukan dan menghasilkan kapasitas yang lebih besar yaitu 250kg per jam daripada teknologi sebelumnya yang hanya mampu memotong 50-56kg per jam. Dengan adanya peningkatan kapasitas pemotongan, maka akan meningkat pula kapasitas produksi. Teung MOCAF Solusindo telah memunehi standar SNI untuk Tepung MOCAF dan memiliki citra morfologi tidak berbeda dengan tapioca yang merupakan karkateristik asal dari singkong.

\section{UCAPAN TERIMA KASIH}

Penulis mengucapkan terimakasih kepada Universitas Diponegoro sesuai dengan Surat Perjanjian Penugasan Pelaksanaan Kegiatan Program Pengabdian Kepada Masyarakat Nomor : 808.03/UN7.P4.3/PM/2017 melalui Program Penguatan Komoditi Unggulan Masyarakat (PKUM)

\section{DAFTAR PUSTAKA}

Ahit, O.P.; S.E. Abit and M.B. Posas. (1981), Growth and development of Cassava Under The Traditional and The Mukibat System of Planting. Annal of Tropical Research 3(3): 187-198.

Alves, A.A.C. 2002. Cassava Botany and Physiology. CAB International.

Anggraeni, A.A. T.H.W. Handayani dan S. Palupi, (2018), Physical and Sensory Properties of Gluten-Free Modified Cassava Flour-Based 
Cookies, Prosiding Yhe $7^{\text {th }}$ International Seminar on Animal Production Yogyakarta Indonesia

Bigcassava.com. 2007. Proyek Pengembangan Budi Daya Singkong Varietas Darul Hidayah Sebagai Upaya Meningkatkan Taraf Kehidupan Ekonomi Petani, Sekaligus Mengintip Peluang Pengembangan Bahan Baku Biofuel. http://www.bigcassava.com

Cock, J.H. 1992. Ubi Kayu. in Goldsworthy, P.R. dan N.M. Fisher. 1992. Fisiologi Tanaman Budidaya Tropik. Gadjah Mada University Press, Yogyakarta

De Bruijn, G.H. and Bambang Guritno. 1990. Farmer Experimentation With Cassava Planting in Indonesia. Departemen of Tropical Crop Science. Wageningen Agriculture University, Netherlands

Diniyah, N., N. Yuwana, Maryanto, B. H. Purnomo, dan A. Subagio, (2018), Karakterisasi Sera Mocaf (Modified Cassava Flour) Dari Ubikayu Varietas Manis Dan Pahit, Jurnal Penelitian Pascapanen Pertanian Vol 15 No. 3 131-139

Gardner, F.P., R.B. Pearce dan R.L. Mitchell. 1991. Fisiologi Tanaman Budidaya. Penerbit Universitas Indonesia, Jakarta.

Kusumastuti, S dan M. Adriani, (2017), Pengaruh Substitusi Susu Kedelai dan Mocaf (Modified Cassava Flour) Terhadap Daya Terima, Kandungan Serat dan Nilai Ekonomi Produk Es Krim Naga Merah, Amerta Nutrition Vol 3 252260

Suhery, W.N., A. Halim, dan H. Lucida, (2013), Uji Sifat Fisikokimia Mocaf (Modified cassava Flour) dan Pati Singkong Termodifikasi untuk Formulasi Tablet, Jurnal Farmasi Indonesia n Vol. 6 No. 3
Tandrianto, J., D.,K. Mintoko, dan S. Gunawan, (2014), Pengaruh Fermentasi pada Pembuatan Mocaf (Modified Cassava Flour) dengan Menggunakan lactobacillus plantarum terhadap Kandungan Protein, Jurnal Teknik POMITS Vol. 3, No. 2

Pemda. Kab. Karanganyar, (2017), Potensi Pertanian, www.karanganyar.go.id

Putri, N.A., H. Herlina dan A. Subagio, (2018), Karakteristik Mocaf (Modified Cassava Flour) Berdasarkan Metode Penggilingan Dan Lama Fermentasi Jurnal Agroteknologi, Vol. 12 No. 01 79-89.

Priadi, G., F. Setiyoningrum, F. Afiati dan R. Syarief, (2018), Pemanfaatan modified cassava flour dan tepung tapioka sebagai bahan pengisi keju cedar olahan, Jurnal Litbang Industri - Vol. 8 No. 2, 6776

Wang, W., C.E. Hostettler, F.F. Damberger, J. Kossmann, J.R. Lloyd and S.C. Zeeman, (2018), Modification of Cassava Root Starch Phosphorylation Enhances Starch Functional Properties, Frontier in Plant Science, Vol 9 Article 1562 1-14

Yuwono, S.S., K. Febrianto, dan N.S. Dewi, (2013), Pembuatan Beras Tiruan Berbasis Modified Cassava Flour (Mocaf): Kajian Proporsi Mocaf : Tepung Beras Dan Penambahan Tepung Porang, Jurnal Teknologi Pertanian Vol. 14 No. 3, 175182. 